\title{
Law enforcement pertaining to illicit trafticking in rhinoceros horn and other trophies
}

\author{
J. WRIGHT
}

Wright, J. 1989. Law enforcement pertaining to illicit trafficking in rhinoceros horn and other trophies. - Koedoe 32 (2): 77-79. Pretoria. ISSN 0075 6458.

The effective police control of illegal traffic in game trophies, as well as the procedures used by law enforcement officers in their investigations are discussed. It is also very relevant to wildlife officers dealing with law enforcement to be aware of, and to understand the statutory restraints placed on their methods of investigation by law. Existing law enforcement bodies on the international scene are mentioned.

Key words: Interpol, game trophies, police, rhinoceros horn, investigative procedures, Commission Regatoire, Customs Cooperation Council.

J. Wright, South African Narcotics Bureau, Private Bag X94, Pretoria, 0001 Republic of South Africa.

\section{Introduction}

The traffic in game trophies has reached alarming proportions in the southern African region during the past few years. Accurate statistics are rarely available, but seizures within the region as well as on the overseas market clearly show an increase in this regard. It is ominously clear that no wishful thinking, nor a concerted process of education will have an effect on the incidence of this kind of trafficking. Experience has taught that people trafficking in game trophies can acquire enormous wealth through illegal trade. The already strong black market has also led to an increase in the demand for game trophies. The question is whether this market will ever be saturated. My intention is not to examine in detail the many conservation problems that exist. I believe the main object is to discuss the effective police control of this problem.

\section{Investigative procedures}

The control of illicit trade by police in modern times has become an intricate science. While law enforcement officers find themselves in the strange predicament that sets of rules, statutory laws, and judicial measures have to be followed, the criminal, in contrast, knows no rules. The respected Queensbury Rules are totally discarded.

Hampered and restricted by a code of ethics, the law enforcement officer subsequently has to find acceptable solutions and alternatives. He needs to broaden his mind to increase his knowledge. Illegal investigative techniques can lead to acquittals in court or to the removal of an officer from a case. Society and especially law enforcement officers then often become despondent and disillusioned with the judicial system. It should be our aim to rise above this frame of mind and to strive to better ourselves and our investigation techniques.

Every country in the world has a criminal code according to which it must act. As a first objective, law enforcement officers must be thoroughly familiar with this code and, remaining within its bounds, ultimately be the victors.

The second objective is to ensure a sound knowledge of the statutory legislation covering the law enforcement officer's field of employment. It is essential to have a thorough knowledge of the legislation pertaining to the illicit trade in game, wildlife and trophies such as ivory and 
rhinoceros horn, before embarking on any investigation to ensure that the law enforcement officer covers all loopholes, while staying on the right side of the law.

The evidence aspect of any investigation is probably the most important. The time spent in the preparation of the case docket will be wasted if the law enforcement officer does not know which evidence to present to a court of law. Has the admissibility of evidence been established? What is hearsay evidence and cannot be proved? Has all the documentary evidence been obtained and were all the relevant statements filed? Investigators often fail to take into account the time spent with the criminal who must be afforded the opportunity of providing an explanation. If an alibi or explanation is presented, it must be examined.

In most countries in the world including the Republic of South Africa, any accused person has the right to remain silent when faced with an accusation. When law enforcement officers are confronted with this problem, why do they accuse? During the investigation leading to the confrontation of the criminal, many facts have usually not yet been established. The best strategy would be to confront the offender under the pretence of trying to establish these facts from him. Thus he remains a witness compelled by law to assist the investigator, and not the accused who may choose not to reveal anything.

Bearing the above in mind, investigators should remember to take note of the conduct of the accused. Courts of law rely on evidence relating to the conduct behaviour of accused persons who are faced with the facts. The right to remain silent when accused of an offence, may compel the court to deduce that the accused could not prove his innocence.

It is essential to remember that the primary function of courts of law is to establish the truth. It is possible, though, that an alibi or exculpatory explanation not based upon the truth, can be refuted by intelligent investigation.

Once a confession has been obtained from an accused, law enforcement officers tend to relax, believing that there is nothing more for them to do until the date of trial. Always remember the golden rule, that every admission of guilt or confession has to be substantiated by additional evidence. Once the proceedings are instituted in court, it may be too late to cover loopholes in the evidence.

The importance of an interview with a criminal or suspected criminal cannot be stressed too strongly. He is the transgressor and therefore knows exactly how he broke the law. He holds all the clues to the puzzle and it is the task of the investigating officer to extract the crucial evidence from him in order to complete the picture.

\section{Law enforcement bodies}

Law enforcement bodies are of the utmost importance in diminishing poaching activities. Agencies such as Interpol and the Customs Cooperation Council (CCC) cooperate on a bilateral and a multilateral basis to ensure that international fugitives from justice do not escape prosecution. Interpol takes care of the police investigations, whereas the $\mathrm{CCC}$ takes care of investigations relating to customs and excise matters. In my opinion it is important that we now take cognizance of, and cooperate with these highly efficient investigative bodies. Although both Interpol and the CCC have their headquarters in Europe, it is common practice for international criminals, especially where illicit trading is concerned, to disregard international borders or boundaries. Recent new agreements on closer cooperation regarding the combating of crime have been established. Most countries in Europe as well as the USA have passed legislation to accommodate the principle of Commission Regatoire. By virtue of these agreements evidence can be taken by such a legal commission anywhere in the western world, as long as there is cooperation between the two governments concerned.

International warrants of arrest have now become commonplace. 
Extradition orders are being revised to ensure that criminal organisations do not escape prosecution by crossing international borders.

\section{Conclusion}

Can we in sub-Saharan Africa work towards a similar multilateral cooperative agreement and is it possible for us (the RSA and its neighbours) to find a solution to stop criminals from exploiting our heritage? We should not only ask this question, but also supply the answer. 